\title{
Utilization of Popcorn for Gluten Free Cake and Cookies Manufacturing
}

\author{
Manal S. Helal and Haiat M.N. Afifi
}

Food Technology Research Institute, Agri. Res. Center, Giza, Egypt. Received: 25 Oct. 2020 / Accepted 20 Dec. 2020 / Publication date: 30 Dec. 2020

\begin{abstract}
Nowadays, the main task of food producers is to make new tasty gluten-free products with an elevated nutritive value to enrich the menu of celiac patients. One of such products could be sweets, such as cake and cookies. Therefore, unpuffing popcorn flour (raw popcorn flour RPF), puffing popcorn corn flour (PPF) and a mixture (1:1) from them, in addition to corn flour as a control sample, were used to prepare gluten-free cake and cookies formulas. The lowest amylose content $(19.81 \%)$ of corn flour followed by raw popcorn flour $(22.97 \%)$ and popped popcorn $(24.95 \%)$. Gluten free cake prepared from popped popcorn (PPF) recorded the highest volume $\left(395 \mathrm{~cm}^{3}\right)$, weight $(201.51 \mathrm{~g})$, height $(6.63 \mathrm{~cm})$ and specific volume $\left(2.22 \mathrm{~cm}^{3} / \mathrm{g}\right)$, while gluten free cake prepared from RPF had the lowest values which were $367.33 \mathrm{~cm} 3,185.42 \mathrm{~g}, 4.75 \mathrm{~cm}$ and $1.94 \mathrm{~cm}^{3} / \mathrm{g}$, respectively. The highest Fracturability was recorded in the control $(65.25 \mathrm{~N})$ while the lowest value $(53.48 \mathrm{~N})$ was recorded in PPF cookies. The lowest rate of Hardness values was noticed after storage period (5 days) in PPF cake samples. Rate of chewiness, gumminess and resilience also were the lowest values in PPF cake samples. Generally, PPF based cookies (cake prepared from popped popcorn) were more acceptable as it had the highest overall acceptability sensory attributes in both prepared cake and cookies.
\end{abstract}

Keywords: popcorn, cake, cookies, physical properties, sensory attributes

\section{Introduction}

Maize is the third most cultivated cereal after wheat and rice in the world. The most important maize varieties are flint corn, dent corn, flour or soft corn as well as popcorn (Donkeun et al., 2000). The major component of the corn kernel is starch and starch is responsible for the mechanical properties of the dough and consequently plays an important role as a determinant of the food product quality (Bhattacharyya et al., 2013).

Popcorn is cereal grains originated from a wild grass (Zea mays Everta). Human consume popcorn as snacks. Popcorn provides a full complement of nutrition benefits, including dietary fiber, protein and essential micronutrient (Ijarotimi and Keshinro, 2011).

Popping is a simultaneous starch gelatinization and expansion process, during which grains are exposed to high temperatures for short time. During this process, super-heated vapor produced inside the grains by instantaneous heating, cooks the grain and suddenly expands the endosperm suddenly, breaking out the outer skin. Puffing is a similar process; differ from popping as a process in which controlled expansion of kernel is carried out, while the vapor pressure escapes through the microprobes of the grain structure due to the high pressure or thermal gradient. Popping and puffing imparts an acceptable taste and a desirable aroma to the snacks (Mishra et al., 2014).

Celiac disease $(\mathrm{CD})$ is a permanent inflammatory disease of the small intestine triggered by the ingestion of gluten containing cereals. It is an immune-mediated disorder that affects primarily the gastrointestinal tract. Intestinal symptoms can include diarrhea, abdominal cramping, pain, and distention, and untreated celiac disease may lead to vitamin and mineral deficiencies, osteoporosis, and other extra intestinal problems. Celiac disease is a genetically-determined chronic inflammatory intestinal disease induced by gluten in wheat, barley, rye etc. Celiac disease affects approximately one percent of people in the world and strict gluten-free diet (GFD) for a lifetime is the only available treatment. As gluten-free products available in the market are known to have a low nutritional quality as well as are more expensive than gluten-containing food products, there is a strong need to develop gluten-free products that are nutritionally complete as well as economical (Jnawali et al. , 2016). 
Although the structure-forming ability of gluten influences the rheological properties of dough and affects overall appearance of bakery products, the development of a gluten network in biscuit and cookie dough is minimal and undesirable (Gallagher et al., 2004).

Therefore, the objective of the present study was to prepare gluten-free popcorn cookies and cakes which targeting a good sensory attributes and quality parameters for celiac patients.

\section{Materials and Methods}

\section{Materials}

Corn (Zea mays var. saccharata) grains were obtained from El-Haram Milling Company, Faisal, Giza. Whole popcorn (Zea mays var. everta, which is a well known variety could successfully be popped) was obtained from local market. Carboxy methyl cellulose (CMC) was obtained from Egyptian International Trade Company, Giza. All other ingredients like sugar, butter, baking powder, eggs and vanilla were obtained from local market in Dokki, Giza governorate, Egypt.

\subsection{Methods}

\subsection{Popping of popcorn}

Popping process of the successful corn variety grains were performed by roasting using a closed heating medium (hot air up to $200-220^{\circ} \mathrm{C}$ for 3 min.). The untreated (raw grains, RPF) and popped (PPF) treated gains as well as corn grains were milled using a Hummer mill to obtain whole flour and sieved through 425 Micron sievers to obtain required refined flour (Jaybhaye et al., 2014).

\subsubsection{Preparation of cakes}

Cake was prepared by the described method of the AACC (2000), with some modifications: Wheat flour was replaced by $100 \%$ corn flour (control), $100 \%$ raw popcorn flour (RPF), $100 \%$ puffing popcorn flour (PPF) and mixture (1:1) of RPF and PPF. Storage was carried for 1.3 and 5 days at room temperature $\left(25 \pm 2^{\circ} \mathrm{C}\right)$.

\subsubsection{Preparation of cookies}

Cookies dough was prepared according to Singh et al., (2008) with some modifications. Four formulas were prepared as follow: $100 \mathrm{~g}$ corn flour (Control), $100 \mathrm{~g}$ purchased untreated popcorn flour (RPF), $100 \mathrm{~g}$ prepared puffing popcorn flour (PPF) or $100 \mathrm{~g}$ mixture (1:1) of RPF and PPF.

\subsubsection{Proximate analysis}

Proximate analyses for moisture, ash, fat, crude fiber and protein contents of the raw material and products were carried out using AOAC (2000) methods. Total carbohydrates were calculated by differences on dry weight basis using following formula:

Total carbohydrate $=100-($ fat + fiber + ash + protein $)$.

Amylose content of raw materials was determined according to the method of Juliano, (1971). Amylopectin was calculated by following equation:

$\%$ Amylopectin $=100-\%$ amylose.

\subsubsection{Water Activity}

Water activity of cakes was measured at zero time and after 1.3 and 5 days using a Rotronic Hygro Lab water activity meter EA10-SCs (Switzerland) at $25 \pm 2^{\circ} \mathrm{C}$. Samples were crushed into small pieces and a representative sample was placed into plastic cups and measured one at a time

\subsection{Physical properties of the gluten free products.}

\subsubsection{Physical properties of the cakes.}

The volume of the cake was determined by seed displacement (Chopin, S.A, France). The cake was weighed after removal from the pan. A digital caliber was used to measure the cake heights according to the AACC method 10-91 (AACC, 2000). Density $\left(\mathrm{g} / \mathrm{cm}^{3}\right)$ and specific volume $\left(\mathrm{cm}^{3} / \mathrm{g}\right.$ ) were calculated by dividing the weight by volumes grains and volumes by weight grains, respectively. Crumb texture of cake was determined by Texture Pro CT V1.6 Build analyzer (Brookfield Engineering Lab. Inc., Middleboro, MA 02346- 1031, USA) provided with the software "Texture Expert". An 
Aluminium 25mm diameter cylindrical probe was used in a "Texture Profile Analysis" (TPA) double compression test to penetrate to $50 \%$ depth, at $1 \mathrm{~mm} / \mathrm{s}$ speed test, with a $30 \mathrm{~s}$ delay between first and second compression. Firmness $(\mathrm{N})$, gumminess $(\mathrm{N})$, chewiness $(\mathrm{mJ})$, adhesiveness $(\mathrm{mJ})$, cohesiveness, springiness $(\mathrm{mm})$ and resilience were calculated by difference between 1, 3 and 5 days from zero time.

\subsection{Physical properties of the cookies.}

\subsubsection{Diameter and thickness}

Diameter and thickness were measured according to the method of the AACC, (2000) and the spread ratio was calculated by dividing diameter (length) by thickness as described by Shrestha and Noomhorm, (2002).

\subsubsection{Fracturability}

Fracturability was determined by the Texture Pro CT V1.6 Build analyzer (TPA) previously mentioned and according to the method of AACC, (2000).

\subsubsection{Functional Properties of raw materials}

Water Absorption Capacity (WAC) and Oil Absorption Capacity (OAC) of raw materials were carried out according to the method of Sofi et al., (2013).

\subsubsection{Sensory evaluation of cakes and cookies}

Cake samples were evaluated on the basis of acceptability of their appearance, odor, taste, flavor, texture, and overall preference, according to Gambus' et al., (2009). Basing on the total points, the overall consumer acceptance was rated: $<2.90$ unacceptable, $3.0-3.50$ acceptable, $3.51-4.50$ good and $4.51-5.0$ very good. Cookies samples were evaluated for their sensory characteristics after baking by ten panelists from the staff of Bread and Pastry, Research Dept., Food Technol. Res. Institute., Agr. Res. Center, Giza. The scoring scheme was established as mentioned by Meilgaard et al., (2007).

\section{Statistical analysis}

Mean values and standard deviation of the analytical data were reported. The obtained data were subjected to one-way analysis of variance (ANOVA) at $\mathrm{P}<0.05$. It was performed and the results were separated using the Multiple Range Duncan's test using the SPSS (2007) statistical software version 16.0 .

\section{Results and Discussion}

\section{Gross chemical composition of raw materials}

Data presented in Table (1) revealed that corn flour had the highest moisture content $(10.12 \%)$ followed by raw popcorn flour (9.05\%) and popped popcorn (4.64\%). Reduction in moisture content of popped popcorn flour may be attributed to popping process which turns the moisture to steam (Landsberg, 2003). A significant difference ( $p>0.05 \%)$ in protein content was observed among the raw materials used.

Table 1: Gross chemical composition of raw materials

\begin{tabular}{lcccccc}
\hline Raw materials & Moisture & $\begin{array}{c}\text { Crude } \\
\text { protein* }^{*}\end{array}$ & Fat* $^{*}$ & Ash* $^{*}$ & $\begin{array}{c}\text { Crude } \\
\text { fiber* }\end{array}$ & $\begin{array}{c}\text { Total* } \\
\text { carbohydrates }\end{array}$ \\
\hline $\begin{array}{l}\text { Corn flour } \\
\begin{array}{l}\text { Untreated Popcorn } \\
\text { flour (RPF) }\end{array}\end{array}$ & $10.12^{\mathrm{a}}$ & $9.03^{\mathrm{a}}$ & $0.84^{\mathrm{b}}$ & $0.74^{\mathrm{b}}$ & $0.77^{\mathrm{b}}$ & $88.62^{\mathrm{a}}$ \\
$\begin{array}{l}\text { Popped Popcorn } \\
\text { flour (PPF) }\end{array}$ & $9.05^{\mathrm{b}}$ & $8.70^{\mathrm{b}}$ & $1.07^{\mathrm{a}}$ & $0.81^{\mathrm{a}}$ & $1.18^{\mathrm{a}}$ & $88.24^{\mathrm{a}}$ \\
\hline
\end{tabular}

* (\% on dry weight basis)

Each mean value, within the same column, followed by the same letter is not significantly different at $\mathrm{P}>0.05$ level.

Corn flour had the lowest values of fat and ash contents ( 0.845 and $0.74 \%$, respectively), while there were significant differences between corn in relative to raw and popped popcorn flours. Popped 
popcorn flour recorded the highest fiber content $(1.24 \%)$ while corn flour recorded the lowest value $(0.77 \%)$. No significant difference $(\mathrm{p}>0.05)$ in carbohydrates content was observed among the used raw material. Carbohydrates content was $88.62,88.24$ and $88.36 \%$ for Corn flour, raw popcorn flour (RPF) and popped popcorn flour (PPF), respectively.

Similar results of chemical composition of corn flour were obtained by Hegazy (2017) who reported that corn flour contained $12.43 \%$ moisture, $9.40 \%$ protein, $3.56 \%$ fat, $0.66 \%$ fiber, $0.79 \%$ ash and $85.58 \%$ carbohydrates. These results, also, agreed with those obtained by Ijarotimi and Keshinro (2011) who stated that raw popcorn contained $12.13,6.86,1.49,1.12$ and $78.3 \%$ for protein, fat, ash, fiber and carbohydrates, respectively.

The nutritional composition of popcorn showed that it contained $8.1-10.5 \%$ crude protein, $0.07-$ $0.23 \%$ reducing sugars and $61.0-67.9 \%$ starch, in which $27.0-28.5 \%$ of the starch was amylose (Donkeun et al., 2000).

\section{Amylose, amylopectin, water holding capacity and oil holding capacity of raw materials}

Corn flour had the lowest amylose content (19.81\%) followed by popcorn flour $(22.97 \%)$ and popped popcorn (24.94\%) (Table 2). The highest value of amylopectin was observed in corn flour $(80.19 \%)$. These results are confirmed by the data reported by Al-Fauomy et al., (2017) who reported that amylose and amylopectin contents of corn flour were 19.81 and $80.19 \%$, respectively.

Water absorption capacity (WAC) is an important parameter that determines the ability of starch to use in products manufacturing. It represents the ability of a substance to associate with water under a limited water condition. It affects functional properties such as viscosity, which is a very important indicator of bulking and consistency of products (Capule and Trinidad, 2016). Water absorption capacity (WAC) of corn flour, raw popcorn and popped popcorn flour were 53.18, 58.03 and 276.20 $\mathrm{ml} .100 \mathrm{gm}^{-1}$, respectively (Table 2). The differences in WAC values were attributed to the variation of their granule structure. The engagement of hydroxyl groups to form hydrogen and covalent bonds between starch chains lowers WAC (Hoover and Sosulski, 1986). Increasing of WHC of popped popcorn may be due to the popping process. Sompong et al., (2011) stated that when linear amylose and starch granule were gelatinized, extrusion induced fragmentation and, due to the starch damage caused by the fragmentation, WAC was increased.

The loose association of amylose and amylopectin molecules in the native starch granules has been observed to be responsible for high WAC (Soni et al., 1987).

The oil absorption capacity of the used materials was $37.64,38.8$ and $55.27 \mathrm{ml} .100 \mathrm{gm}^{-1}$ for corn flour, RPF and PPF, respectively. Similar results were obtained by Al-Fauomy (2017) and Ijarotimi and Keshinro (2011).

Table 2: Amylose, Amylopectin, water and oil absorption capacity properties of raw materials used for preparing gluten free cakes and cookies.

\begin{tabular}{lcccc}
\hline Raw materials & $\begin{array}{c}\text { Amylose } \\
\mathbf{( \% )}\end{array}$ & $\begin{array}{c}\text { Amylopectin } \\
(\mathbf{\%})\end{array}$ & $\begin{array}{c}\text { WAC ml/100gm } \\
\mathbf{( \% )}\end{array}$ & $\begin{array}{c}\text { OAC ml/100gm } \\
\mathbf{( \% )}\end{array}$ \\
\hline Corn flour & 19.81 & 80.19 & 53.18 & 37.64 \\
Raw popcorn flour & 21.97 & 78.03 & 58.03 & 38.80 \\
Popped popcorn flour & 24.94 & 75.06 & 276.2 & 55.27 \\
\hline
\end{tabular}

\section{Chemical composition of gluten free products}

\subsection{Chemical composition of gluten free cakes}

Table (3) shows the chemical composition of gluten free cakes. Control had the highest value of protein $(6.72 \%)$. No significant $(\mathrm{p}<0.05 \%)$ difference was observed among the other formulas. This may be attributed to the slightly difference among the chemical composition of raw materials (Table 1). Control cake samples, had the highest fat content value (14.02\%) and the lowest content of fiber $(0.32 \%)$ while there was no significant difference $(\mathrm{p}<0.05 \%)$ among the other formulas. No significant differences were observed in ash contents among the formulas, which ranged between 1.38 and $1.60 \%$. There was a significant difference in total carbohydrates content among the formulas. Carbohydrates content ranged from 77.34 for control to $79.60 \%$ for PPF, PPF MIX. 
Table 3: Chemical composition of cookies (\% on dry weight basis)

\begin{tabular}{lclccc}
\hline Cookies samples & Protein & Fat & Fiber & Ash & Carbohydrates \\
\hline Control & $6.72^{\mathrm{a}}$ & $14.02^{\mathrm{a}}$ & $0.32^{\mathrm{b}}$ & $1.60^{\mathrm{a}}$ & $77.34^{\mathrm{c}}$ \\
RPF & $6.45^{\mathrm{b}}$ & $13.62^{\mathrm{b}}$ & $0.49^{\mathrm{a}}$ & $1.38^{\mathrm{a}}$ & $78.06^{\mathrm{b}}$ \\
PPF & $6.32^{\mathrm{b}}$ & $13.56^{\mathrm{b}}$ & $0.51^{\mathrm{a}}$ & $1.50^{\mathrm{a}}$ & $78.11^{\mathrm{b}}$ \\
RPF, PPFMIX & $6.35^{\mathrm{b}}$ & $13.54^{\mathrm{b}}$ & $0.50^{\mathrm{a}}$ & $1.41^{\mathrm{a}}$ & $79.60^{\mathrm{a}}$ \\
\hline
\end{tabular}

Control: cakes prepared from $100 \%$ corn flour, RPF: cakes prepared from 100\% RPF, PPF: cakes prepared from 100\% PPF and RPF, PPFMIX: cakes prepared from 50:50 RPF and PPF.

Each mean value, within the same column, followed by the same letter is not significantly different at $\mathrm{P}>0.05$ level.

\subsection{Chemical composition of gluten free cookies}

Table (4) shows the chemical composition of gluten free cookies prepared from raw, popped popcorn and their mixture $(1: 1)$ in relative to control samples. No significant difference in protein content between control (4.19\%) and PPF (3.94\%), whereas, its contents decreased in RPF (3.80\%) and RPF (3.68\%). This may be attributed to the composition of raw materials of formulae. Control cookies sample had the highest fat contents (14.94\%) whereas there was no significant difference among the other formulae. For fiber content, there was no significant difference among formulae RPF, PPf and RPF, PPF MIX while control had the lowest value $(0.51 \%)$. On contrary, no significant difference was observed in ash and carbohydrates contents among the formulae and control.

Table 4: Chemical composition of cookies (\% on dry weight basis)

\begin{tabular}{lllllc}
\hline Cake samples & Protein & Fat & Fiber & Ash & Carbohydrates \\
\hline Control & $4.19^{\mathrm{a}}$ & $14.94^{\mathrm{a}}$ & $0.51^{\mathrm{b}}$ & $0.80^{\mathrm{a}}$ & $79.56^{\mathrm{a}}$ \\
RPF & $3.68^{\mathrm{b}}$ & $14.57^{\mathrm{b}}$ & $0.74^{\mathrm{a}}$ & $0.83^{\mathrm{a}}$ & $80.18^{\mathrm{a}}$ \\
PPF & $3.94^{\mathrm{a}}$ & $14.28^{\mathrm{b}}$ & $0.70^{\mathrm{a}}$ & $0.82^{\mathrm{a}}$ & $80.26^{\mathrm{a}}$ \\
RPF,PPF MIX & $3.80^{\mathrm{b}}$ & $14.38^{\mathrm{b}}$ & $0.79^{\mathrm{a}}$ & $0.81^{\mathrm{a}}$ & $80.22^{\mathrm{a}}$ \\
\hline
\end{tabular}

Control: cookies prepared from 100\% corn flour, RPF: cookies prepared from 100\% RPF, PPF: cookies prepared from 100\% PPF and RPF, PPFMIX: cookies prepared from 50:50 RPF and PPF.

Each mean value, within the same column, followed by the same letter is not significantly different at $\mathrm{P}>0.05$ level.

\section{Physical properties}

\subsection{Physical properties of gluten free cakes}

High-quality cakes have various attributes, including high volume, uniform crumb structure, tenderness, shelf life and tolerance to staling (Ge'linas et al., 1999). These attributes depend on the balanced formulas.

As can be seen in Table (5), gluten free cake prepared from PPF recorded the highest volume $\left(395.0 \mathrm{~cm}^{3}\right)$, weight $(201.51 \mathrm{~g})$, height $(6.36 \mathrm{~cm})$ and specific volume $\left(2.22 \mathrm{~cm}^{3} / \mathrm{g}\right)$, while gluten free cake prepared from RPF had the lowest values which were $367.33 \mathrm{~cm}^{3}, 185.42 \mathrm{~g}, 4.75 \mathrm{~cm}$ and 1.94 $\mathrm{cm}^{3} / \mathrm{g}$. Cake expansion is greatly dependent on starch gelatinization temperature, obtaining better dough expansion at high gelatinization temperatures (Rosell et al., 2011). So that, thus higher cake expansion and in turn higher specific volume would be expected resulting of popping process.

Table 5: Physical properties of gluten free cakes

\begin{tabular}{|c|c|c|c|c|c|}
\hline Cake samples & $\begin{array}{c}\text { Volume } \\
\left(\mathrm{cm}^{3}\right)\end{array}$ & $\begin{array}{c}\text { Weight } \\
\text { (g) }\end{array}$ & $\begin{array}{c}\text { Height } \\
\text { (cm) }\end{array}$ & $\begin{array}{l}\text { Density } \\
\left(\mathrm{g} / \mathrm{cm}^{3}\right)\end{array}$ & $\begin{array}{c}\text { Specific } \\
\text { volume } \\
\left(\mathrm{cm}^{3} / \mathrm{g}\right)\end{array}$ \\
\hline Control & $370.00^{b}$ & $185.25^{b}$ & $5.52^{b}$ & $0.50^{\mathrm{a}}$ & $1.99^{b}$ \\
\hline RPF & $367.33^{b}$ & $185.42^{b}$ & $4.75^{\mathrm{d}}$ & $0.51^{\mathrm{a}}$ & $1.94^{\mathrm{b}}$ \\
\hline PPF & $395.00^{\mathrm{a}}$ & $201.51^{\mathrm{a}}$ & $6.36^{\mathrm{a}}$ & $0.50^{\mathrm{a}}$ & $2.22^{\mathrm{a}}$ \\
\hline RPF, PPFMIX & $385.00^{\mathrm{c}}$ & $186.89^{b}$ & $5.05^{\mathrm{c}}$ & $0.48^{\mathrm{a}}$ & $2.06^{b}$ \\
\hline
\end{tabular}

Control: cakes prepared from 100\% corn flour, RPF: cakes prepared from 100\% RPF, PPF: cakes prepared from 100\% PPF and RPF, PPFMIX: cakes prepared from 50:50 RPF and PPF.

Each mean value, within the same column, followed by the same letter is not significantly different at $\mathrm{P}>0.05$ level. 


\subsection{Physical properties of gluten free cookies}

Physical analysis of cookies is an important factor for both consumers as well as manufacturers point of view. Results in Table (6) indicated the physical properties of the cookies prepared from corn flour, RPF, PPF or mixture of RPF and PPF (1:1). No significant difference ( $>0.05 \%)$ in diameter was noticed among all cookie samples except cookies prepared from $100 \%$ popped popcorn flour which recorded the lowest value $(43.43 \mathrm{~mm})$. This may be attributed to an increase in fiber content of popped popcorn (as previously mentioned and confirmed by (Omran and Hussien, 2015). Diameter values were 44.77, 44.87 and $43.87 \mathrm{~mm}$ for control, RPF and RPF, PPFMIX, respectively.

No significant difference $(\mathrm{p}>0.05 \%)$ in thickness was observed between control and formula 1 which recorded the highest values (4.47 and $4.48 \mathrm{~mm}$, respectively) and there was no significant difference $(\mathrm{p}>0.05 \%)$ between formula 2 and formula 3 which recorded the lowest values $(4.27$ and $4.37 \mathrm{~mm}$, respectively).

Table 6: Physical properties of gluten free cakes

\begin{tabular}{lccccc}
\hline $\begin{array}{l}\text { Cookies } \\
\text { samples }\end{array}$ & Fracturability & $\begin{array}{c}\text { Diameter } \\
(\mathbf{m m})\end{array}$ & $\begin{array}{c}\text { Thickness } \\
(\mathbf{m m})\end{array}$ & $\begin{array}{c}\text { Spread } \\
\text { ratio }\end{array}$ & $\begin{array}{c}\text { Weight } \\
(\mathbf{g})\end{array}$ \\
\hline Control & $65.25^{\mathrm{a}}$ & $44.77^{\mathrm{a}}$ & $4.47^{\mathrm{a}}$ & $10.02^{\mathrm{a}}$ & $6.71^{\mathrm{c}}$ \\
RPF & $59.67^{\mathrm{b}}$ & $44.87^{\mathrm{a}}$ & $4.48^{\mathrm{a}}$ & $10.01^{\mathrm{a}}$ & $7.80^{\mathrm{a}}$ \\
PPF & $53.48^{\mathrm{c}}$ & $43.43^{\mathrm{b}}$ & $4.27^{\mathrm{b}}$ & $10.18^{\mathrm{a}}$ & $6.85^{\mathrm{c}}$ \\
RPF, PPF MIX & $54.45^{\mathrm{bc}}$ & $43.87^{\mathrm{b}}$ & $4.37^{\mathrm{b}}$ & $10.05^{\mathrm{a}}$ & $7.47^{\mathrm{b}}$ \\
\hline
\end{tabular}

Control: cookies prepared from 100\% corn flour, RPF: cookies prepared from 100\% RPF, PPF: cookies prepared from $100 \%$ PPF and RPF, PPFMIX: cookies prepared from 50:50 RPF and PPF.

Each mean value, within the same column, followed by the same letter is not significantly different at $\mathrm{P}>0.05$ level.

Although there were significant differences in diameter and thickness among some samples, no significant differences were observed in spread ratio among the samples, which ranged from 10.01 to 10.18 (Table 6).

It has been established that cookies spread is strongly correlated to the water absorption capacities of the flour (Vieira et al., 2007). Since the water absorption capacity of popped popcorn flour is higher than that of corn flour and raw popcorn flour, rapid partition of free water to hydrophilic sites of popped popcorn flour is presumed to be higher than corn flour.

There was a significant difference in weight among the cookie samples where cookie prepared from RPF had the highest value $(7.80 \mathrm{~g})$ compared the control $(6.71 \mathrm{~g})$.

Physical analysis of cookies is an important factor for both consumers as well as manufacturers point of view. Results in Table (6) indicated the physical properties of the cookies prepared from corn flour, RPF, PPF or mixture of RPF and PPF (1:1). No significant difference ( $>0.05 \%)$ in diameter was noticed among all cookie samples except cookies prepared from $100 \%$ popped popcorn flour which recorded the lowest value $(43.43 \mathrm{~mm})$. This may be attributed to an increase in fiber content of popped popcorn (as previously mentioned and confirmed by Omran and Hussien (2015). Diameter values were 44.77, 44.87 and $43.87 \mathrm{~mm}$ for control, RPF and RPF, PPF MIX, respectively.

No significant difference ( $>0.05 \%)$ in thickness was observed between control and formula 1 which recorded the highest values (4.47 and $4.48 \mathrm{~mm}$, respectively) and there was no significant difference $(\mathrm{p}>0.05 \%)$ between formula 2 and formula 3 which recorded the lowest values $(4.27$ and $4.37 \mathrm{~mm}$, respectively).

Although there were significant differences in diameter and thickness among some samples, no significant differences were observed in spread ratio among the samples, which ranged from 10.01 to 10.18 (Table 6).

It has been established that cookies spread is strongly correlated to the water absorption capacities of the flour (Vieira et al., 2007). Since the water absorption capacity of popped popcorn flour is higher than that of corn flour and raw popcorn flour, rapid partition of free water to hydrophilic sites of popped popcorn flour is presumed to be higher than corn flour.

There was a significant difference in weight among the cookie samples where cookie prepared from RPF had the highest value (7.80 g) compared the control $(6.71 \mathrm{~g})$.

Fracturability is the textural property which attracts more attention in evaluation of baked goods, due to its close association with human perception of freshness (Karaoğlu and Kotancilar, 2009). The importance of cookies texture in consumer acceptance is increasingly recognized. Significant 
differences in fracturability observed in cookie samples. The highest fracturability value was in the control $(65.25 \mathrm{~N})$ sample while PPF cookies recorded the lowest value $(53.48 \mathrm{~N})$. Decreasing in hardness of PPF cookies may due to that popped popcorn flour is potentially hydrophilic in nature, and thereby, absorbed excessive moisture and affected the fracturability.

The texture of baked biscuits is primarily attributable to starch gelatinization, and super cooled sugar rather than a protein/starch structure (Gallagher, 2004). This may be the reason for decrease in Fracturability of the PPF cookies. According to Seyhun et al., (2003), the increased hardness can be attributed to the amylose and amylopectin re-crystallization, to the formation of complexes between starch and proteins, and to redistribution of water between the components of the product, as well as other events which may occur in this baked product during storage.

\section{Effect of storage period on water activity of gluten free cakes}

The water activity level in food is of practical importance as it controls the onset and severity of mold spoilage. It is commonly observed that foods most likely to show rapid deterioration, due to biological and chemical changes are usually those with high water content (Abdullaha et al., 2000)

Water activity is an important factor in determining the physical (firmness) changes of bread crumb during storage (Lazaridou et al., 2007). Lower $\mathrm{a}_{\mathrm{w}}$ has been associated with the increase in the firmness of breads. According to Miyazaki et al., (2004), when the differences in the $\mathrm{a}_{\mathrm{w}}$ value of the bread crumb is minimal during storage indicated retrogradation would be retarded, and bread staling will be slow. Water activity of gluten free cake samples stored in the current study for 1, 3 and 5 days was determined and results are presented in Table (7). Water activity of control didn't significantly affect during the storage period, while RPF, PPF MIX formula had an opposite trend which significantly decreased after $1^{\text {st }}$ day till the end of storage where decreased from 0.821 to 0.789 .

Table 7: Water activity of stored gluten free cakes

\begin{tabular}{lcccc}
\hline Cake samples & \multicolumn{4}{c}{ Storage period } \\
\cline { 2 - 5 } & Zero time & $\mathbf{1}^{\text {st }}$ day & $\mathbf{3}^{\text {rd }} \mathbf{d a y}$ & $\mathbf{5}^{\text {th }}$ day \\
\hline Control & $0.783^{\mathrm{a}}$ & $0.783^{\mathrm{a}}$ & $0.779^{\mathrm{a}}$ & $0.779^{\mathrm{a}}$ \\
RPF & $0.830^{\mathrm{a}}$ & $0.829^{\mathrm{a}}$ & $0.821^{\mathrm{a}}$ & $0.819^{\mathrm{b}}$ \\
PPF & $0.823^{\mathrm{a}}$ & $0.823^{\mathrm{a}}$ & $0.818^{\mathrm{a}}$ & $0.816^{\mathrm{b}}$ \\
RPF, PPF MIX & $0.821^{\mathrm{a}}$ & $0.792^{\mathrm{b}}$ & $0.789^{\mathrm{b}} \pm$ & $0.789^{\mathrm{b}}$ \\
\hline
\end{tabular}

Control: cakes prepared from $100 \%$ corn flour, RPF: cakes prepared from 100\% RPF, PPF: cakes prepared from 100\% PPF and RPF, PPFMIX: cakes prepared from 50:50 RPF and PPF.

Each mean value, within the same row, followed by the same letter is not significantly different at $\mathrm{P}>0.05$ level.

Water activity of formulas RPF and PPF slightly affected during the storage period except at the end of storage which significantly decreased from 0.830 to 0.819 and from 0.823 to 0.816 for formula RPF and PPF, respectively.

This can be attributed to higher Water Holding Capacity of popped popcorn than corn flour (Rosell et al., 2001).

\section{Texture evaluation of gluten free cakes.}

Fig. 1 presents rate of texture parameters for 1, 3 and 5 days stored gluten free cake samples. Hardness values $(\mathrm{N})$ of formula PPF were the lowest during storage period (at each of the 5 days). These results might have been caused by WAC and structure of starch molecule (Table 2). Starch retrogradation occurs when starch molecules begin to reassociate in an ordered structure (Atwell et al., 1988). Amylose aggregation and crystallization have been reported to be complete within the first few hours of storage while amylopectin aggregation and crystallization occur during later stages (Miles et al., 1985). 


\section{Hardness (N)}

a storage 1 day $\square$ storage 3 day $\square$ storage 5 day

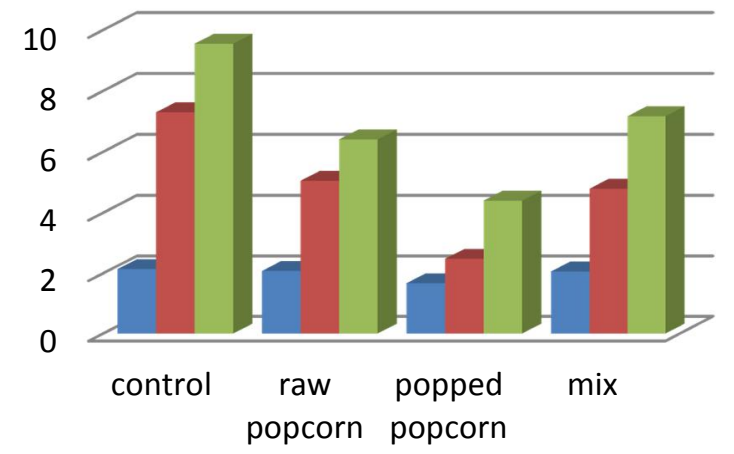

\section{Springness (mm)}

a storage 1 day $\square$ storage 3 day $\square$ storage 5 day

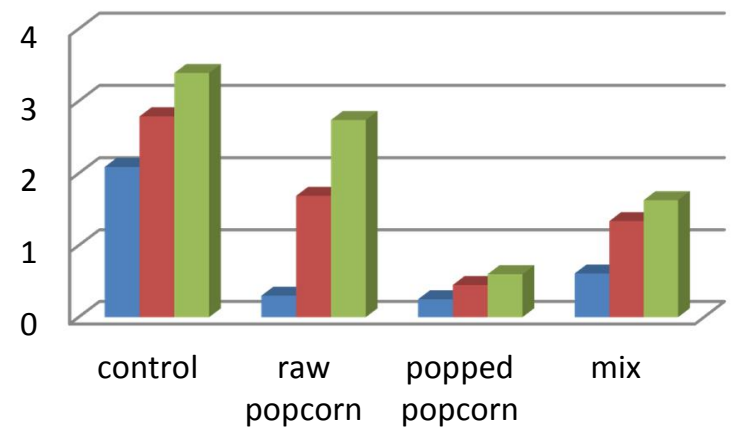

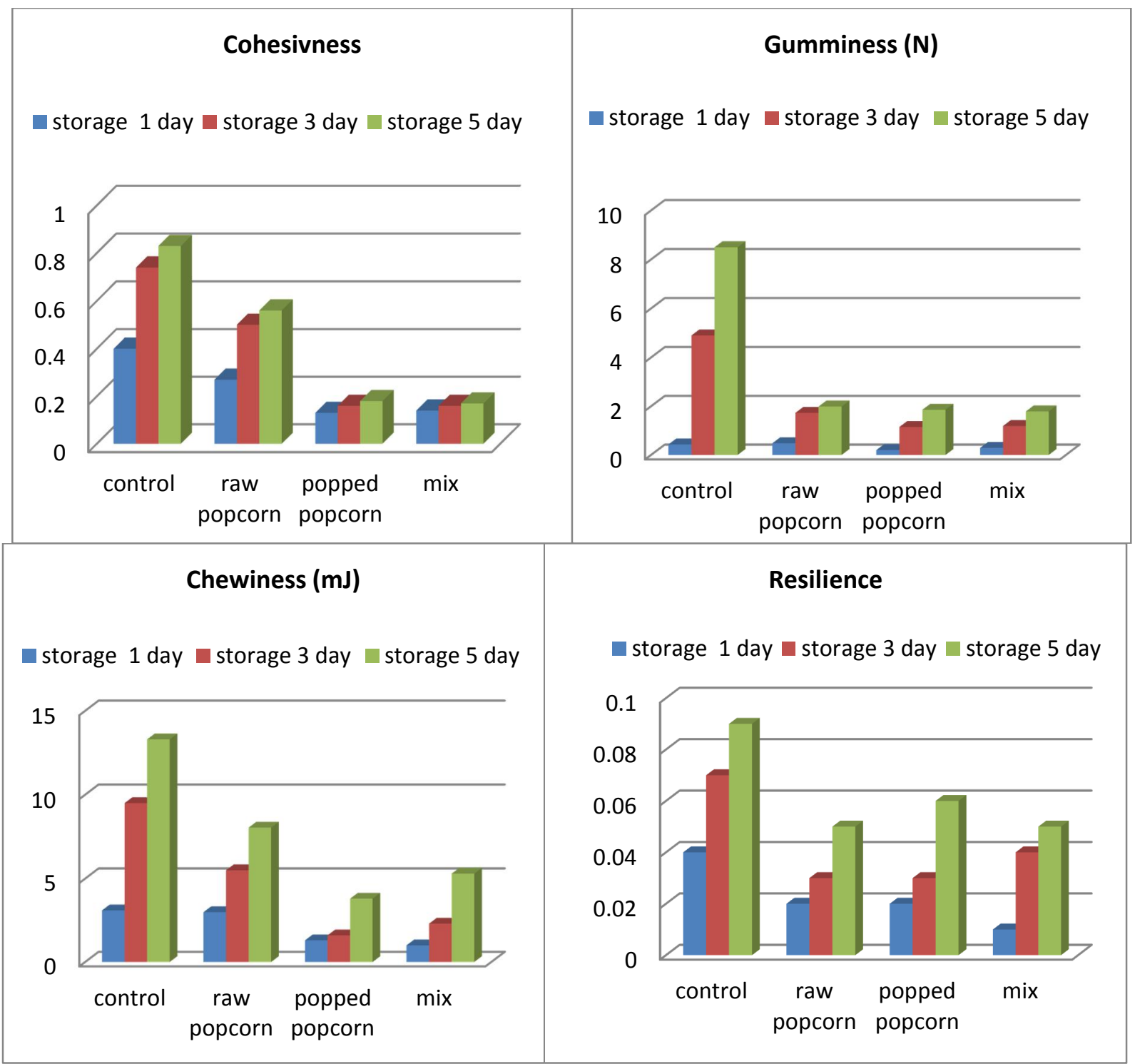

Fig. 1: Rate of texture parameters of stored gluten free cakes. 
Chewiness is one of the texture parameters easily correlated with sensory analyses through trained panels (Esteller et al., 2004). Rate of chewiness and gumminess, as well as resilience (except at 5 days of storage), in PPF formula cake samples, also, were the lowest values with ageing. Both, gumminess and chewiness are parameters dependent on firmness; therefore, their values, in both of fresh and stored cakes followed a similar trend as of firmness. The rat of properties in these values was higher in the case of cake prepared from corn flour, PPF or mixture of RPF and PPF (1:1). Similar results were obtained by Gambus et al., (2009) who stored sponge cake prepared from corn flour, potato starch and amaranth flour for 4 days.

On contrary, it was observed that with increasing of the storage period of gluten free cake, cohesiveness and springiness values decreased. Cohesiveness quantifies the internal resistance of food structure. Regarding the behavior during storage a general decrease in cohesiveness was observed. A similar result was also, obtained in other baked goods (Esteller et al., 2004). A subjective evaluation of springiness is normally made by consumers and consists of slightly pressing the piece of food, by hand or with the mouth, and verifying how easily it returns to the original size. Regarding springiness change during storage, a decrease was observed during storage. Control sample recorded the highest decreasing, while the lowest decreasing was observed in the case of cake prepared from PPF individual and its mixture with RPF.

\section{Sensory evaluation of gluten free products}

\subsection{Sensory evaluation of gluten free cakes}

Hedonic sensory evaluation of corn and popcorn based gluten free cakes were shown in Table (8). Gluten free cake prepared from PPF had the highest values for appearance (4.94), color (4.81), texture (4.56) and overall acceptability (4.56). Meanwhile, no significant differences ( $>0.05)$ were noticed among the other formulas. In corn based cakes, the high protein content of formulation could be caused an acceleration of maillard reaction which is produced dark-brown substances (Levent and Bilgiçli, 2011).

Significant differences $(\mathrm{p}>0.05 \%)$ weren't observed in flavor and taste among formulas prepared from RPF, PPF or their mixture (1:1) compared to the control which recorded the lowest values $(3.63$ and 3.31, respectively). This may be refer to higher Oil Absorption Capacity (OAC) of raw popcorn or popped popcorn flours than corn flour where Oil Holding Capacity $(\mathrm{OHC})$ is the ability of the dry starch to physically bind fat by capillary attraction and it is of great importance, as fat acts as a flavor retainer and also increases the mouthfeel of foods, (Ali et al., 2016).

Table 8: Sensory evaluation of gluten free Cakes.

\begin{tabular}{lcccccc}
\hline \multicolumn{1}{c}{ Cake samples } & Appearance & Color & Flavor & Taste & Texture & $\begin{array}{c}\text { over all } \\
\text { Acceptability }\end{array}$ \\
\hline Control & $3.50^{\mathrm{c}}$ & $4.13^{\mathrm{b}}$ & $3.63^{\mathrm{b}}$ & $3.31^{\mathrm{b}}$ & $3.75^{\mathrm{bc}}$ & $3.50^{\mathrm{b}}$ \\
RPF & $3.81^{\mathrm{b}}$ & $4.25^{\mathrm{b}}$ & $4.19^{\mathrm{ab}}$ & $4.06^{\mathrm{a}}$ & $3.63^{\mathrm{b}}$ & $3.63^{\mathrm{b}}$ \\
PPF & $4.94^{\mathrm{a}}$ & $4.81^{\mathrm{a}}$ & $4.56^{\mathrm{a}}$ & $4.63^{\mathrm{a}}$ & $4.56^{\mathrm{a}}$ & $4.56^{\mathrm{a}}$ \\
RPF, PPF MIX & $3.87^{\mathrm{b}}$ & $4.40^{\mathrm{b}}$ & $4.22^{\mathrm{ab}}$ & $4.44^{\mathrm{a}}$ & $4.39^{\mathrm{ab}}$ & $3.77^{\mathrm{b}}$ \\
\hline
\end{tabular}

Control: cakes prepared from 100\% corn flour, RPF: cakes prepared from 100\% RPF, PPF: cakes prepared from 100\% PPF and RPF, PPFMIX: cakes prepared from 50:50 RPF and PPF.

Each mean value, within the same column, followed by the same letter is not significantly different at $\mathrm{P}>0.05$ level.

These results are similar to those of Gambus et al., (2009) who reported that the gluten free sponge cake based on corn flour were accepted by the panelists (scores over 4.51).

From the above data, it could be observed that gluten free cake prepared from PPF was more acceptable by panelist and recorded the highest scores than other three samples. Generally, it could be concluded that popped popcorn flour could be used in prepared gluten free cake samples with highly acceptable sensory characteristics.

\subsection{Sensory evaluation of Gluten free cookies}

Sensory evaluation is a unique discipline that makes use of experimental design and statistical analysis concepts to human senses with the aim of evaluating consumer products (Kuenzel et al., 2011). 
Sensory evaluation of gluten free cookies prepared from corn flour, RPF, PPF and mixture of RPF and PPF (1:1) is presented in Table (9). There was no significant difference $(\mathrm{p}>0.05 \%)$ in color between control and cookies prepared from PPF which recorded the highest values (9.5 and 8.83, respectively). No significant difference was also observed between RPF and RPF, PPF mix formula which had the lowest ones (7.67 and 8.00, respectively). Flavor of cookie samples has taken the same trend of color. For appearance of cookie samples, no significant difference was noticed among the formulas except formula prepared from RPF which had the lowest value (7.83) compared to the control. In general PPF based cookies were more acceptable as it had the highest overall acceptability similar to the control.

Consequently, it could be concluded that popped popcorn flour could be recommended as a successful materials to prepare gluten free cake and cookies products than the others, followed by formula 3 (8.47) and PPF formula (7.10). This could be attributed to higher Oil Absorption Capacity (OAC) of popped popcorn flour as fat acts as flavor retainer and also increases the mouthfeel of foods, (Ali et al., 2016).

Table 9: Sensory evaluation for gluten free cookies

\begin{tabular}{cccccc}
\hline Cookies samples & Color & Appearance & Flavor & Taste & Overall acceptability \\
\hline Control & $9.50^{\mathrm{a}}$ & $9.33^{\mathrm{a}}$ & $9.90^{\mathrm{a}}$ & $9.90^{\mathrm{a}}$ & $9.83^{\mathrm{a}}$ \\
RPF & $7.67^{\mathrm{b}}$ & $7.83^{\mathrm{b}}$ & $8.83^{\mathrm{b}}$ & $7.10^{\mathrm{c}}$ & $7.07^{\mathrm{b}}$ \\
PPF & $8.83^{\mathrm{a}}$ & $8.67^{\mathrm{ab}}$ & $9.66^{\mathrm{a}}$ & $9.90^{\mathrm{a}}$ & $9.17^{\mathrm{a}}$ \\
RPF, PPF MIX & $8.00^{\mathrm{b}}$ & $8.67^{\mathrm{ab}}$ & $8.83^{\mathrm{b}}$ & $8.47^{\mathrm{b}}$ & $7.67^{\mathrm{b}}$
\end{tabular}

Control: Cookies prepared from 100\% corn flour, RPF: Cookies prepared from 100\% RPF, PPF: Cookies prepared from 100\% PPF and RPF, PPFMIX: Cookies prepared from 50:50 RPF and PPF.

Each mean value, within the same column, followed by the same letter is not significantly different at $\mathrm{P}>0.05$ level.

\section{References}

AACC, 2000. Approved methods of American Association of Cereal Chemists (10 ${ }^{\text {th }}$ ed.). Published by American Association of Cereal Chemists, Ins. Saint Paul, Minnesota, USA.

AOAC, 2000. Official Methods of Analysis (1 $7^{\text {th }}$ Ed.). Arlington, VA: Association of Official Analytical Chemists, AOAC International.

Abdullaha, N., A. Nawawia, and I. Othmanb, 2000. Fungal spoilage of starch-based foods in relation to its water activity $\left(\mathrm{a}_{\mathrm{w}}\right)$, Journal of Stored Products Research, 36 (1): 47 -54.

Al-Fauomy, G.A., Ibrahim, Ola, S. and Ali, Mona, M.A. 2017. Physico-chemical Characteristics of

Starches from Different Cereal Grains. American Journal of Food Science and Technology, 5 (4): 125134.

Ali, A., T.A. Wani, I.A. Wani, and F.A. Masoodi, 2016. Comparative study of the physico -chemical properties of rice and corn starches grown in Indian temperate climate. Journal of the Saudi Society of Agric. Sci., 15: 75-82.

Atwell, W.A., L. Hood, D. Lineback, E. Varriano-Marston, and H. Zohel, 1988. The terminology and methodology associated with basic starch phenomenon. Cereal Foods World, 33: 306-311.

Bhattacharyya, P., U. Ghosh, H. Gangopadhyay, and U. Raychaudhuri, 2013. Effects of thermal treatments and germination on physico-chemical properties of corn flour. African Journal of Food Science Research, 1(1):10-14

Capule, A.B. and T.P. Trinidad, 2016. Isolation and characterization of native and modified starch from adlay (Coix lacryma jobi-L.). Intern. Food Res. J., 23(3): 1199-1206.

Donkeun, P., G.D.A. Kenneth, F.R. Stermitz, and J.A. Maga, 2000. Chemical composition and physical characteristics of unpopped popcorn hybrids. J. Food Composition Analy., 13(6): 921-934.

Esteller, M.S., R.L. Amaral, and S.C.S. Lannes, 2004. Effect of sugar and fat replacers on the texture of baked goods. J. Texture Studies, 35: 383- 393.

Gallagher, E., T.R. Gormley, and E.K. Arendt, 2004. Recent advances in the formulation of gluten-free cereal-based products. Food Science and Technology, 15(3-4): 143-152.

Ge'linas, P., G. Roy, and M. Guillet, 1999. Relative effects of ingredients on cake staling based on an accelerated shelf-life test. Journal of Food Science, 64: 937-940. 
Gambus', H., F. Gambus', D. Pastuszka, P. Wrona, R. Ziobro, R. Sabat, B. Mickowska,; A. Nowotna, and M. Sikora, 2009. Quality of gluten-free supplemented cakes and biscuits. International Journal of Food Sciences and Nutrition, 60 (S4): 31-50

Hegazy, H.S. 2017. Studies on some new products prepared from cereals and vegetables blends by extrusion. Ph D. Fac. of Agic., Menoufia Univ., Egypt.

Hoover, R. and F. Sosulski, 1986. Effect of cross linking on functional properties of legume starches. Starch/ Starke, 38: 149-155.

Ijarotimi, S.O. and O.O. Keshinro, 2011. Determination of Amino Acid, Fatty Acid, Mineral, Functional and Choking Properties of Germinated and Fermented Popcorn (Zea mays everta) Flour. European Journal of Food Research and Review, 1(2): 102-122.

Jaybhaye, R.V., I.L. Pardeshi, P.C. Vengaiah, and P.P. Srivastav, 2014. Processing and technology for millet based food products: a review. Journal of Ready to Eat Food, 1(2): 32-48.

Jnawali, P., V. Kumar, and B. Tanwar, 2016. Celiac disease: Overview and considerations for development of gluten-free foods. Food Science and Human Wellness, 5: 169-176.

Juliano, B.O., 1971. A simplified assay for milled rice amylose. Cereal Sci. Today, 16(11): 334-339.

Karaoğlu, M.M. and H.G. Kotancilar, 2009. Quality and textural behaviour of par-baked and rebaked cake during prolonged storage. Inter. J. Food Sci. Tech., 44: 93-99.

Kuenzel, J., E.H. Zandstra, W. El Deredy, I. Blanchette, and A. Thomas, 2011. Expecting yoghurt drinks to taste sweet or pleasant increases liking. Appetite, 56(1): 122-127.

Landsberg, R. 2003. Popcorn Cooking with Phase Changes Popcorn Board website-http://kicpyerkes.uchicago.edu/2003-winter/pdf/ywi2003-popcorn .pdf P. $1-7$.

Lazaridou, A., D. Duta, M. Papageorgiou, C. Belc, and C.G. Biliaderis, 2007. Effects of hydrocolloids on dough rheology and bread quality parameters in gluten-free formulations. Journal of Food Engineering, 79: 1033-1047.

Levent, H. and N. Bilgiçli, 2011. Effect of Gluten-Free Flours on Physical Properties of Cakes. Journal of Food Science and Engineering, 1: 354-360.

Meilgaard, M.C., G.V. Civileand, and B.T. Carr, 2007. Nutritive value and chemical composition of pseudocereals as gluten-free ingredients. Int. J. of Food Sci. and Nut., 60: 240-257.

Miles, M.J., V.J. Morris, R.D. Orford, and S.G. Ring, 1985. The roles of amylose and amylopectin in the gelatin and retrogradation of starch. Carbohy. Res., 135: 271-281.

Mishra, G., D.C. Joshi, and B.K. Panda, 2014. Popping and Puffing of Cereal Grains: A Review. Journal of Grain Processing and Storage, 1 (2): 34 - 46.

Miyazaki, M., T. Maeda, and N. Morita, 2004. Effect of various dextrin substitutions for wheat flour on dough properties and bread qualities. Food Research International, 37: 59-65.

Omran, A.A. and H.A. Hussien, 2015. Production and evaluation of gluten-free cookies from broken rice flour and sweet potato. Advances of food sciences, 37 (4): $184-191$.

Rosell, C.M., J.M. Rojas, and C. Benedito de Barber, 2001. Influence of hydrocolloids on dough rheology and bread quality. Food Hydrocolloids, 15: 75-81.

Rosell, C.M., W. Yokoyama, and C. Shoemaker, 2011. Rheology of different hydrocolloids-rice starch blends. Effect of successive heating-cooling cycles. Carbohydrate Polymers, 84(1): 373-382.

Seyhun, N., G. Sumnu, and S. Sahin, 2003. Effects of different emulsifier types, fat contents, and gum types on retardation of staling of microwave-baked cakes. Nahrung, 47: 248-251.

Shrestha, A.K. and A. Noomhorm, 2002. Comparison of physico-chemical properties of biscuits supplemented with soy and kinema flours. Inter. J. of Food Science Tech., 37 (4): 361 - 368.

Singh, S., C.S. Riar, and D.C. Saxena, 2008. Effect of incorporating sweet potato flour to wheat flour on the quality characteristics of cookies. African J. Food Sci., 2: 65-72.

Sofi, B.A., I.A. Wani, F.A. Masoodi, I. Saba, and S. Muzaffar, 2013. Effect of gamma irradiation on physicochemical properties of broad bean (Vicia faba L.) starch. LWT - Food Science and Technology, 54 (1): 63-72.

Sompong, R., S. Siebenhandl-Ehn, E. Berghofer, and R. Schoenlechner, 2011. Extrusion cooking properties of white and coloured rice varieties with different amylose content. Starch/Stärke, 63: 55-63

Soni, P.L., H.W. Sharma, S.S. Bisen, H.C. Srivastava, and M.M. Gharia, 1987. Unique physicochemical properties of sal (Shorea robusta) starch. Starch, 23: 8-11. 
SPSS, 2007. Statistical Package for the Social Sciences. SPSS for Windows, Version 16.0. Chicago, SPSS Inc.

Vieira, M.A., K.C. Tramonte, R. Podestá, S.R.P. Avancini, R.D.M.C. Amboni, and E.R. Amante, 2007. Physicochemical and sensory characteristics of cookies containing residue from king palm (Archontophoenix alexandrae) processing. Int. J. Food Sci. Tech., 43: 1534-1540. 